Article

\title{
Immobilization of Lead and Zinc Leached from Mining Residual Materials in Kabwe, Zambia: Possibility of Chemical Immobilization by Dolomite, Calcined Dolomite, and Magnesium Oxide
}

\author{
Pawit Tangviroon ${ }^{1, *}$, Kenta Noto ${ }^{2}$, Toshifumi Igarashi ${ }^{1}$, Takeshi Kawashima ${ }^{3}$, Mayumi Ito ${ }^{1}$, \\ Tsutomu Sato ${ }^{1}\left(\mathbb{D}\right.$, Walubita Mufalo ${ }^{2} \mathbb{D}$, Meki Chirwa ${ }^{4}$, Imasiku Nyambe ${ }^{4}$, Hokuto Nakata ${ }^{5}$, \\ Shouta Nakayama ${ }^{5}$ and Mayumi Ishizuka ${ }^{5}$ \\ 1 Division of Sustainable Resources Engineering, Faculty of Engineering, Hokkaido University, \\ Sapporo 060-8628, Japan; tosifumi@eng.hokudai.ac.jp (T.I.); itomayu@eng.hokudai.ac.jp (M.I.); \\ tomsato@eng.hokudai.ac.jp (T.S.) \\ 2 Division of Sustainable Resources Engineering, Graduate School of Engineering, Hokkaido University, \\ Sapporo 060-8628, Japan; kn1855@docon.jp (K.N.); wmufalo@gmail.com (W.M.) \\ 3 Yoshizawa Lime Industry Co., LTD., Libra Bldg, 3-2 Nihonbashi-Kobuncho, Chuo-Ku, \\ Tokyo 103-0024, Japan; tkawashi@yoshizawa.co.jp \\ 4 IWRM Centre/Geology Department, School of Mines, The University of Zambia, Lusaka 32379, Zambia; \\ meki.chirwa@gmail.com (M.C.); inyambe@gmail.com (I.N.) \\ 5 Faculty of Veterinary Medicine, Hokkaido University, Kita 18, Nishi 9, Kita-Ku, Sapporo 060-0818, Japan; \\ hokuto.nakata@vetmed.hokudai.ac.jp (H.N.); shouta-nakayama@vetmed.hokudai.ac.jp (S.N.); \\ ishizum@vetmed.hokudai.ac.jp (M.I.) \\ * Correspondence: tangviroon.p@eng.hokudai.ac.jp or tangviroon.p@gmail.com; Tel.: +81-90-6217-0676
}

Received: 22 July 2020; Accepted: 24 August 2020; Published: 28 August 2020

check for updates

\begin{abstract}
Massive amount of highly contaminated mining residual materials (MRM) has been left unattended and has leached heavy metals, particularly lead $(\mathrm{Pb})$ and zinc $(\mathrm{Zn})$ to the surrounding environments. Thus, the performance of three immobilizers, raw dolomite (RD), calcined dolomite $(\mathrm{CD})$, and magnesium oxide (MO), was evaluated using batch experiments to determine their ability to immobilize $\mathrm{Pb}$ and $\mathrm{Zn}$, leached from MRM. The addition of immobilizers increased the leachate $\mathrm{pH}$ and decreased the amounts of dissolved $\mathrm{Pb}$ and $\mathrm{Zn}$ to different extents. The performance of immobilizers to immobilize $\mathrm{Pb}$ and $\mathrm{Zn}$ followed the following trend: $\mathrm{MO}>\mathrm{CD}>\mathrm{RD}$. $\mathrm{pH}$ played an important role in immobilizing $\mathrm{Pb}$ and $\mathrm{Zn}$. Dolomite in $\mathrm{RD}$ could slightly raise the $\mathrm{pH}$ of the MRM leachate. Therefore, the addition of $\mathrm{RD}$ immobilized $\mathrm{Pb}$ and $\mathrm{Zn}$ via adsorption and co-precipitation, and up to $10 \%$ of $\mathrm{RD}$ addition did not reduce the concentrations of $\mathrm{Pb}$ and $\mathrm{Zn}$ to be lower than the effluent standards in Zambia. In contrast, the presence of magnesia in CD and MO significantly contributed to the rise of leachate $\mathrm{pH}$ to the value where it was sufficient to precipitate hydroxides of $\mathrm{Pb}$ and $\mathrm{Zn}$ and decrease their leaching concentrations below the regulated values. Even though $\mathrm{MO}$ outperformed $\mathrm{CD}$, by considering the local availability of $\mathrm{RD}$ to produce $\mathrm{CD}, \mathrm{CD}$ could be a potential immobilizer to be implemented in Zambia.
\end{abstract}

Keywords: mine waste; contamination; batch experiments; lead; zinc; immobilization; remediation; Kabwe; Zambia

\section{Introduction}

Kabwe District was one of the most important mining regions in Zambia for almost a century (1902-1994). It was regarded as Southern Africa's principal lead ( $\mathrm{Pb})$-zinc (Zn) producer, producing 
over 1.8 and $0.8 \mathrm{Mt}$ of $\mathrm{Zn}$ and $\mathrm{Pb}$, respectively [1]. While in operation, no pollution laws were enforced to regulate the discharge from wastes of the mine; therefore, operations of the mine have left Kabwe with a massive amount of unattended mining residual materials (MRM), which still contain elevated amounts of heavy metals, particularly $\mathrm{Zn}, \mathrm{Pb}$, and iron (Fe). Weathering of MRM causes heavy metals to transport from the contaminated sites to the surrounding environments (groundwater, surface water, and soil) [2]. In particular, the redistribution of heavy metals through solute transport processes has been reported to be one of the most dangerous pathways, which invokes harmful effects on water sources of nearby ecosystems and health-threatening to the nearby residents [3-9]. Therefore, the remediation of heavy metals in and around the mine is necessary.

In our recent studies, several potential remediation techniques have been investigated to remediate the contaminated site in Kabwe. Silwamba et al. $(2020)[10,11]$ have proposed the concurrent dissolution and cementation method. The method shows promising results in terms of $\mathrm{Pb}$ removal and recovery. However, Zn could not be effectively recovered from the extraction solution, and further investigation is needed. Biocementation by locally available bacteria has been studied by Mwandira et al. (2019) [12,13] The results indicate that the biocemented material can be effectively used as a covering layer to prevent airborne contamination of metallic dust and infiltration of water into the waste. In the present study, chemical immobilization is introduced as an alternative and practical method to remediate the site.

Remediation techniques for heavy metals polluted sites can be classified into two main categories, in-situ and ex-situ. In general, ex-situ treatment has high efficiency; however, it is less cost-effective than in-situ remediation due significantly to the costs for excavation and transport of large quantities of contaminated materials. In-situ remediation avoids the excavation and transportation costs because of on-site treatments of contaminants. Various kinds of in-situ remediation techniques have been developed to immobilize or extract the heavy metals in the contaminated sites. Among them, chemical immobilization is cheap, easy to implement, and quick in execution [14,15]. Thus, this is the most promising technique, especially to be applied in one of the developing countries.

In in-situ chemical immobilization, the leaching potential of heavy metals from contaminated soils is reduced via sorption and/or precipitation processes by adding chemical agent (immobilizer) into the contaminated area. The performance of a variety of immobilizers, including carbonates, phosphates, alkaline agents, clay, iron-containing minerals, and organic matters, has been evaluated [14-23]. However, most of the studies have been conducted to remediate contaminated soil samples in which they generally contain much lesser metals contents than those in MRM. Moreover, because of the complex interactions between solutes and immobilizers, the definite efficiency of the immobilizer remains site-specific. In other words, there is no guarantee on the effectiveness of a particular immobilizer implemented on different contaminated sites. Therefore, the objective of this study was to evaluate and compare the performance of selected potential immobilizers (e.g., locally available, low-cost) to reduce the mobility of $\mathrm{Pb}$ and $\mathrm{Zn}$ leached from the highly contaminated sample (MRM).

It is necessary to apply immobilizers that is low cost and abundant in nature for remediating contaminated areas. Hence, in this study, raw dolomite (RD) was selected as one of the potential candidates because it is naturally available in a large quantity in Zambia [24]. It is a carbonate mineral; therefore, it can increase and buffer $\mathrm{pH}$ of MRM, leading to more adsorption and precipitation of cationic heavy metal ions [25-27]. In the present study, calcined dolomite (CD) was also used as an immobilizer. The heat treatment was performed to change the carbonate property of dolomite to be more alkaline [28]. As a result, the immobilizer was expected to strongly increase the $\mathrm{pH}$ of MRM, favoring the immobilization of heavy metals by hydroxide precipitation in addition to adsorption and precipitation of other secondary minerals. At the same time, commercially available alkaline-based agent, magnesium oxide (MO), was also tested to compare the ability of RD and CD on immobilizing heavy metals in MRM. The current study will provide meaningful information for the development of chemical immobilization to remediate heavy metals contaminated sites in Zambia. 


\section{Materials and Methods}

\subsection{Solid Sample Collection, Preparation, and Characterization}

MRM was collected from the dumping site of $\mathrm{Pb}-\mathrm{Zn}$ mine wastes in Kabwe, Zambia. The sampling was done using shovels at random points within the area shown in Figure 1. This leaching residual was selected as one of the representative wastes because the leaching concentrations of $\mathrm{Zn}$ and $\mathrm{Pb}$ from the waste were higher compared with the other wastes. Moreover, the storage size of this waste occupies more than $50 \%$ of the total dumping area. The sample was stored in vacuum bags and transported to the laboratory in Japan with permission by the Ministry of Agriculture, Forestry, and Fisheries of Japan. In preparation, it was air-dried under ambient conditions, lightly crushed, sieved using a $2 \mathrm{~mm}$ aperture screen, and kept in a polypropylene bottle before use. Particle sizes of less than 2 mm were chosen to follow the Japanese standard for the leaching test of contaminated soils [29].

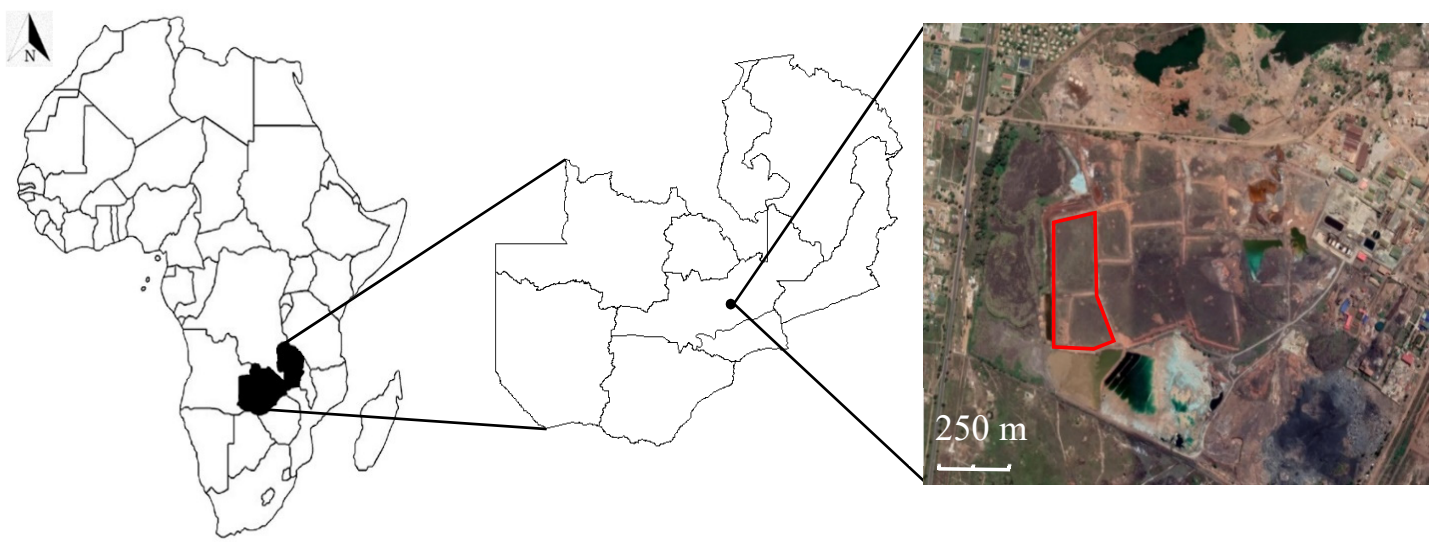

Figure 1. Dumping site in Kabwe; ( $\square$ ) sampling area (top left: $14^{\circ} 27^{\prime} 39^{\prime \prime}$ South, $28^{\circ} 25^{\prime} 42^{\prime \prime}$ East; down right: $14^{\circ} 27^{\prime} 55^{\prime \prime}$ South, $28^{\circ} 26^{\prime} 16^{\prime \prime}$ East).

Three types of immobilizing agents were selected to immobilize $\mathrm{Zn}$ and $\mathrm{Pb}$ in the waste: raw dolomite, calcined dolomite, and magnesium oxide denoted as $R D, C D$, and $M O$, respectively. RD was taken from a dolomite quarry source near the MRM storage site, while CD was prepared by burning $\mathrm{RD}$ with particle sizes of less than $2 \mathrm{~mm}$ in a furnace at $700{ }^{\circ} \mathrm{C}$ for $2 \mathrm{~h}$. MO was commercially available, purchased from Ube Industry, Japan. The same preparation procedure as that for MRM was also applied to these materials.

Chemical and mineralogical properties of all solid samples were characterized on the pressed powder of finely crushed samples $(<50 \mu \mathrm{m})$ using an X-ray fluorescence spectrometer (XRF) (Spectro Xepos, Rigaku Corporation, Tokyo, Japan) and X-ray diffractometer (XRD) (MultiFlex, Rigaku Corporation, Tokyo, Japan), respectively. Sequential extraction was conducted to evaluate solid-phase heavy metals speciation of MRM. The procedure used in this study was modified from two well-known procedures, Tessier et al. (1979) [30] and Clevenger (1990) [31]. The modification was done by Marumo et al. (2003) [32], and it was widely used to extract the tailings sample, mineral processing wastes, and leaching residues [10,33-36]. The process can divide solid-phase heavy metals bounded to solid into five different phases, including exchangeable, carbonates, Fe-Mn oxides, sulfide/organic matter, and residual. The details of the extraction procedure are summarized in Table 1 . The extraction was done on $1 \mathrm{~g}$ of the $<2 \mathrm{~mm}$ MRM sample. Between each step, the extractant solution of the previous step was retrieved by centrifugation of the suspension at $3000 \mathrm{rpm}$ for $40 \mathrm{~min}$ to separate the residue out of the leachate. The residual was then washed with $20 \mathrm{~mL}$ of deionized water. Finally, the washing and extractant solutions were mixed, diluted to $50 \mathrm{~mL}$, filtrated through $0.45-\mu \mathrm{m}$ Millex ${ }^{\circledR}$ filters, and kept in polypropylene bottles prior to chemical analysis. 
Table 1. Sequential extraction for heavy metals speciation.

\begin{tabular}{|c|c|c|c|c|c|c|c|}
\hline Step & Extractant & $\mathrm{pH}$ & $\begin{array}{l}\text { Liquid to } \\
\text { Solid Ratio } \\
(\mathrm{mL} / \mathrm{g})\end{array}$ & $\begin{array}{c}\text { Temperature } \\
\left({ }^{\circ} \mathrm{C}\right)\end{array}$ & $\underset{\text { (h) }}{\text { Duration }}$ & $\begin{array}{c}\text { Mixing } \\
\text { Speed (rpm) }\end{array}$ & Extracted Phase \\
\hline 1 & \multirow{3}{*}{$\begin{array}{c}1 \mathrm{M} \mathrm{MgCl}_{2} \\
1 \mathrm{M} \mathrm{CH}_{3} \mathrm{COOHNa} \\
0.04 \mathrm{M} \mathrm{NH}_{2} \mathrm{OH} \cdot \mathrm{HCl} \\
\text { in } 25 \% \text { acetic acid } \\
0.04 \mathrm{M} \mathrm{NH}_{2} \mathrm{OH} \cdot \mathrm{HCl}\end{array}$} & 7 & 20/1 & 25 & 1 & 120 & Exchangeable \\
\hline 2 & & 5 & $20 / 1$ & 25 & 5 & 120 & Carbonates \\
\hline 3 & & & 20/1 & 50 & 5 & 120 & Reducible \\
\hline 4 & $\begin{array}{c}\text { in } 25 \% \text { acetic acid; } \\
30 \% \mathrm{H}_{2} \mathrm{O}_{2} ; 0.02 \mathrm{M} \\
\mathrm{HNO}_{3}\end{array}$ & & $36 / 1$ & 85 & 5 & 120 & Oxidizable \\
\hline 5 & Calculated & & & & & & Residual \\
\hline
\end{tabular}

\subsection{Batch Leaching Experiments}

Batch leaching experiments were performed using $250 \mathrm{~mL}$ polypropylene Erlenmeyer flasks with a lateral reciprocating shaker (EYELA Multi Shaker MMS, Tokyo Rikakikai Co., Ltd., Tokyo, Japan). All batches were conducted under ambient conditions by mixing $15 \mathrm{~g}$ of solid sample to $150 \mathrm{~mL}$ of deionized water (1:10 solid-to-liquid ratio) at $200 \mathrm{rpm}$ for $6 \mathrm{~h}$. Five replications of the leaching tests of MRM were conducted, while a single run of every immobilization experiment was done. The reason is that in immobilization tests, we adjusted the addition of immobilizers and did not control the $\mathrm{pH}$ of the suspension. In other words, $\mathrm{pH}$ is determined by the complex chemical and physical interactions between immobilizer and MRM. Thus, a variation of $\mathrm{pH}$ can be easily observed even though the same mixing ratio between MRM and immobilizer and the conditions is employed. To avoid the uncertainty of the variation of $\mathrm{pH}$ at the same immobilizer:MRM mixing ratio, we varied the immobilizer:MRM mixing ratios at 1:100, 3:100, 1:20, and 1:10 to evaluate the performance of immobilizers. After $6 \mathrm{~h}$ of shaking, the $\mathrm{pH}$, electrical conductivity (EC), redox potential (ORP), and temperature were immediately measured. The leachates were collected by first centrifuging the mixtures at $3000 \mathrm{rpm}$ for $40 \mathrm{~min}$ to separate the suspended particles. The supernatants were then filtered with $0.45-\mu \mathrm{m}$ Millex ${ }^{\circledR}$ filters (Merck Millipore, Burlington, MA, USA) and kept in air-tight polypropylene bottles prior to chemical analysis.

\subsection{Chemical Analysis of Liquid Samples}

Inductively coupled plasma atomic emission spectrometer (ICP-AES) (ICPE-9000, Shimadzu Corporation, Kyoto, Japan) and inductively coupled plasma atomic emission mass spectrometry (ICP-MS) (ICAP Qc, Thermo Fisher Scientific, Waltham, MA, USA) were used to quantify the dissolved concentrations of heavy metals and coexisting ions. The analyses were performed on the pretreated liquid samples in which $1 \%$ by volume of $60 \%$ nitric acid $\left(\mathrm{HNO}_{3}\right)$ was added to the liquid samples. The acidification was done to make sure that all target elements were in a dissolved form. The non-acidified samples, on the other hand, were used to determine alkalinity or acid resistivity. This parameter is generally reported as bicarbonate concentration (meq/L), quantified by titration of a known volume of sample with $0.01 \mathrm{M}$ sulfuric acid $\left(\mathrm{H}_{2} \mathrm{SO}_{4}\right)$ until $\mathrm{pH}$ 4.8. All chemicals used were reagent-grade.

\subsection{Geochemical Modeling}

An aqueous geochemical modeling program, PHREEQC (Version 3, U.S. Geological Survey, Sunrise Valley Drive Reston, VA, USA) [37], was used to aid in the interpretation of the experimental results. The program can determine the parameters that may affect the mobility of heavy metals from MRM, such as stability of minerals and chemical species. The input data included temperature, $\mathrm{pH}$, ORP, and concentrations of heavy metals and other coexisting ions. Thermodynamic properties were taken from the WATEQ4F database. 


\section{Results and Discussion}

\subsection{Properties of Solid Samples}

The mineralogical and chemical compositions of MRM and immobilizers, including RD, CD, and $\mathrm{MO}$, are listed in Tables 2 and 3, respectively. MRM was composed of anglesite $\left(\mathrm{PbSO}_{4}\right)$ as a primary mineral; zinkosite $\left(\mathrm{ZnSO}_{4}\right)$ and quartz $\left(\mathrm{SiO}_{2}\right)$ as the second-highest; and goethite $(\mathrm{FeOOH})$, hematite $\left(\mathrm{Fe}_{2} \mathrm{O}_{3}\right)$, and gypsum $\left(\mathrm{CaSO}_{4} \cdot 2 \mathrm{H}_{2} \mathrm{O}\right)$ as the miner minerals. Anglesite and zinkosite are commonly found as the weathering products of $\mathrm{Pb}$ - and $\mathrm{Zn}$-sulfides under natural oxygenated environments $[38,39]$. Therefore, the presence of these two minerals indicates that MRM has already been exposed to the surface environment for a long time before the sampling was done. It can also be expected that other than goethite and hematite, MRM also contained amorphous iron-(hydr)oxides and iron-sulfate salts (e.g., melanterite, coquimbite) since goethite and hematite were found as the miner minerals but $\mathrm{Fe}_{2} \mathrm{O}_{3}$ content was the highest among all compositions detected. The contents of $\mathrm{Pb}$ and $\mathrm{Zn}$ in MRM were 10.9\% and 8.1\%, respectively. The values of both metals were extremely high and exceeded the permissible limit in soil, $600 \mathrm{mg} / \mathrm{kg}$ for $\mathrm{Pb}$ and $1500 \mathrm{mg} / \mathrm{kg}$ for $\mathrm{Zn} \mathrm{[40].} \mathrm{However,}$ this does not guarantee that MRM can release significant amounts of $\mathrm{Pb}$ and $\mathrm{Zn}$ since their mobility also depends significantly on the chemical speciation. Sequential extraction was then performed, and the result showed that around $40 \%$ of the total contents of $\mathrm{Pb}$ and $\mathrm{Zn}$ were in mobile fractions (exchangeable, carbonates, and oxidizable) under surface environments (Figure 2). This confirms that MRM could be a potential source contaminating the surrounding environment with $\mathrm{Pb}$ and $\mathrm{Zn}$.

Table 2. Mineralogical composition of solid samples.

\begin{tabular}{ccccc}
\hline & MRM & RD & CD & MO \\
\hline Quartz & ++ & - & - & - \\
Gypsum & + & - & - & - \\
Anglesite & +++ & - & - & - \\
Zinkosite & ++ & - & - & - \\
Hematite & + & - & - & - \\
Goethite & + & - & - & - \\
Dolomite & - & +++ & +++ & - \\
Calcite & - & - & + & - \\
Magnesia & - & - & + & +++ \\
\hline
\end{tabular}

+++: Strong; ++: Moderate; +: Weak; -: None.

Table 3. Chemical composition of solid samples (the unit is in $\mathrm{wt} \%$ ).

\begin{tabular}{ccccc}
\hline & MRM & RD & CD & MO \\
\hline $\mathrm{SiO}_{2}$ & 20.9 & 0.39 & 0.37 & $<0.01$ \\
$\mathrm{TiO}_{2}$ & 0.35 & $<0.01$ & $<0.01$ & $<0.01$ \\
$\mathrm{Al}_{2} \mathrm{O}_{3}$ & 1.91 & 0.24 & 0.11 & $<0.01$ \\
$\mathrm{Fe}_{2} \mathrm{O}_{3}$ & 45.8 & 0.52 & 0.68 & $<0.01$ \\
$\mathrm{MnO}$ & 1.59 & 0.46 & 0.43 & $<0.01$ \\
$\mathrm{MgO}$ & $<0.01$ & 36.9 & 33.3 & 100 \\
$\mathrm{CaO}$ & 4.64 & 60.7 & 62.4 & $<0.01$ \\
$\mathrm{Na}_{2} \mathrm{O}$ & $<0.01$ & $<0.01$ & $<0.01$ & $<0.01$ \\
$\mathrm{~K}_{2} \mathrm{O}$ & $<0.01$ & 0.15 & 0.16 & $<0.01$ \\
$\mathrm{P}_{2} \mathrm{O}_{5}$ & $<0.01$ & 0.14 & $<0.01$ & $<0.01$ \\
$\mathrm{SO}_{3}$ & 2.71 & 0.15 & 0.2 & $<0.01$ \\
$\mathrm{~Pb}$ & 10.9 & $<0.01$ & $<0.01$ & $<0.01$ \\
$\mathrm{Zn}$ & 8.1 & $<0.01$ & $<0.01$ & $<0.01$ \\
\hline
\end{tabular}

The most dominant mineral found in $\mathrm{RD}$ was dolomite $\left(\mathrm{CaMg}\left(\mathrm{CO}_{3}\right)_{2}\right)$. Magnesium $(\mathrm{Mg})$ and calcium (Ca) oxides contents accounted for more than $95 \%$ with a molar ratio of Ca to $\mathrm{Mg}$ of 1.2 . 
This indicates that RD adequately consisted of pure dolomite. Burning RD at $700{ }^{\circ} \mathrm{C}$ for $2 \mathrm{~h}$ generated the new type of immobilizer, $\mathrm{CD}$. Calcite $\left(\mathrm{CaCO}_{3}\right)$ and magnesia $(\mathrm{MgO})$ were detected in addition to dolomite. With almost the same molar ratio of $\mathrm{Ca}$ to $\mathrm{Mg}$ in CD compared with that in RD, it clearly indicates that the calcination process transformed dolomite into calcite and magnesia. MO composed only of magnesia with $100 \% \mathrm{MgO}$ content, which shows pure magnesia.

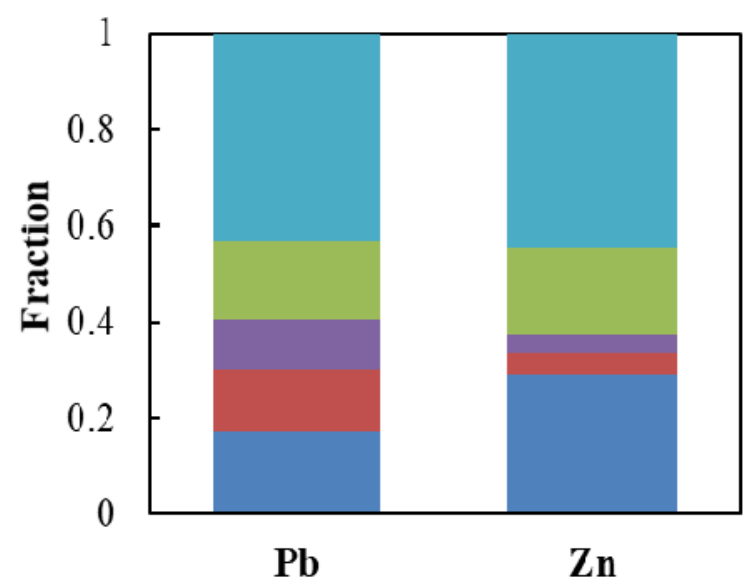

Figure 2. Solid-phase $\mathrm{Pb}$ and $\mathrm{Zn}$ speciation of mining residual materials (MRM); ( $\square$ ) exchangeable, ( $\square$ ) carbonates, ( $\square$ ) sulfide/organic matter, $(\square)$ Fe-Mn oxides, and ( $\square$ ) residual.

\subsection{Leaching Characteristic of MRM}

Table 4 shows the leaching characteristic of MRM. The experimental values were reproducible with high precision since the standard deviations of all parameters were quite small. Four heavy metals, $\mathrm{Pb}$, $\mathrm{Zn}$, cadmium $(\mathrm{Cd})$, and copper $(\mathrm{Cu})$, were leached at the concentrations falling within the instrument detection limits of ICP-AES and -MS. Among these heavy metals, the leaching concentrations of only $\mathrm{Pb}(2.1 \mathrm{mg} / \mathrm{L})$ and $\mathrm{Zn}(365 \mathrm{mg} / \mathrm{L})$ exceeded the effluent standard in Zambia $(0.5 \mathrm{mg} / \mathrm{L}$ for Pb and $1 \mathrm{mg} / \mathrm{L}$ for $\mathrm{Zn}$ ) [41]. Therefore, this study focused only on the mobility of these two metals. PHREEQC simulation on the saturation indices of all possible $\mathrm{Pb}$ - and $\mathrm{Zn}$-minerals showed that with the given conditions and components in MRM leachate, only saturation index of anglesite fell within a common error interval used to indicate saturation equilibrium $( \pm 0.2)$ (Table 5$)$. The result indicates that the low solubility of anglesite restricted the dissolved concentration of $\mathrm{Pb}$, while no restriction by means of precipitation was observed on the leaching of $\mathrm{Zn}$. This can explain why $4.51 \%$ of the total $\mathrm{Zn}$ content was leached from MRM, while only $0.02 \%$ was observed in the case of $\mathrm{Pb}$ leaching.

Table 4. Leaching characteristic of MRM $(n=5)$.

\begin{tabular}{ccc}
\hline & MRM & Reg. Value * $(\mathrm{mg} / \mathrm{L})$ \\
\hline $\mathrm{pH}$ & $5.26 \pm 0.04$ & - \\
$\mathrm{ORP}(\mathrm{mv})$ & $300 \pm 36$ & - \\
$\mathrm{EC}(\mathrm{mS} / \mathrm{cm})$ & $2.7 \pm 0.09$ & - \\
$\mathrm{Pb}(\mathrm{mg} / \mathrm{L})$ & $2.1 \pm 0.008$ & 0.5 \\
$\mathrm{Zn}(\mathrm{mg} / \mathrm{L})$ & $365 \pm 18$ & 1 \\
$\mathrm{Cd}(\mathrm{mg} / \mathrm{L})$ & $0.21 \pm 0.009$ & 0.5 \\
$\mathrm{Cu}(\mathrm{mg} / \mathrm{L})$ & $0.08 \pm 0.01$ & 1.5 \\
$\mathrm{Ca}^{2+}(\mathrm{mg} / \mathrm{L})$ & $547 \pm 48.2$ & - \\
$\mathrm{Mg}^{2+}(\mathrm{mg} / \mathrm{L})$ & $27.7 \pm 3.1$ & - \\
$\mathrm{SO}_{4}{ }^{2-}(\mathrm{mg} / \mathrm{L})$ & $1907 \pm 36.8$ & - \\
$\mathrm{Si}(\mathrm{mg} / \mathrm{L})$ & $13 \pm 0.5$ & -
\end{tabular}

* Regulated value in mg/L specified by the Environment Management Act (2013) [40]. 
Table 5. Calculated saturation indices of possible $\mathrm{Pb}$ - and $\mathrm{Zn}$-minerals in MRM leachate.

\begin{tabular}{cc}
\hline Mineral & Saturation Index \\
\hline Anglesite & -0.2 \\
Cerussite & -2.25 \\
$\mathrm{~Pb}(\mathrm{OH})_{2}$ & -3.4 \\
$\mathrm{Smithsonite}$ & -2.45 \\
Willemite & -3.62 \\
$\mathrm{Zn}(\mathrm{OH})_{2}$ & -3.82 \\
Hydrocerussite & -8.41 \\
Hydrozincite & -3.08 \\
\hline
\end{tabular}

Calcium ion $\left(\mathrm{Ca}^{2+}\right)$ and sulfate ion $\left(\mathrm{SO}_{4}{ }^{2-}\right)$ were the major ions in the leachate, accounting for more than $85 \%$ of the total dissolved ions. These ions were likely to be enriched by the dissolution of soluble phase minerals, such as gypsum and zinkosite [42,43]. However, the dissolution of these two minerals might not only be the sources of $\mathrm{SO}_{4}{ }^{2-}$ since the molar ratio of $\mathrm{Ca}^{2+}$ and $\mathrm{Zn}$ to $\mathrm{SO}_{4}{ }^{2-}$ was lower than one. The sulfide fractions of both metals in MRM (Figure 2), together with the slightly acidic $\mathrm{pH}$ (5.2) and positive ORP $(300 \mathrm{mV})$ of the leachate, suggest that the oxidation of sulfide minerals (e.g., pyrite, galena, sphalerite) and dissolution of iron-sulfate salts (e.g., melanterite, coquimbite) also occurred and attributed to the enrichment of $\mathrm{SO}_{4}{ }^{2-}$, even though they were not detected by XRD. This could also partly contribute to the enrichment of $\mathrm{Pb}$ and $\mathrm{Zn}$ in the leachate.

\subsection{Potential of Immobilizers}

\subsubsection{Effects of Addition of Immobilizers on $\mathrm{pH}$ and Coexisting Ions}

Changes in the $\mathrm{pH}$ of the leachate as a function of the amounts of addition of $\mathrm{RD}, \mathrm{CD}$, and MO are shown in Figure 3. The $\mathrm{pH}$ increased from 5.2 to 6.7, 8.2, and 9.8 with increasing RD, CD, and MO addition from 0 to $10 \%$. When the same amount of immobilizer was added, the performance of the immobilizers to increase the leachate $\mathrm{pH}$ followed the order: $\mathrm{MO}>\mathrm{CD}>\mathrm{RD}$. The results clearly showed the improvement of the alkaline property of $\mathrm{CD}$ over $\mathrm{RD}$. The variation in $\mathrm{pH}$ could mainly be attributed to the liming effect(s) of dolomite (Equation (1)) in RD treatments, of dolomite (Equation (1)), of calcite (Equation (2)), and of magnesia (Equation (3)) in CD treatments, and of magnesia (Equation (3)) in $\mathrm{MO}$ treatments [44-47].

$$
\begin{gathered}
\mathrm{CaMg}\left(\mathrm{CO}_{3}\right)_{2}+2 \mathrm{H}^{+} \Leftrightarrow \mathrm{Ca}^{2+}+\mathrm{Mg}^{2+}+2 \mathrm{HCO}_{3}^{-}, \\
\mathrm{CaCO}_{3}+\mathrm{H}^{+} \Leftrightarrow \mathrm{Ca}^{2+}+\mathrm{HCO}_{3}^{-} \\
\mathrm{MgO}+\mathrm{H}_{2} \mathrm{O} \Leftrightarrow \mathrm{Mg}(\mathrm{OH})_{2} \Leftrightarrow \mathrm{Mg}^{2+}+2 \mathrm{OH}^{-} .
\end{gathered}
$$

Figure $4 \mathrm{a}-\mathrm{c}$ illustrates the leaching concentrations of major coexisting ions, $\mathrm{Ca}^{2+}$, magnesium $\left(\mathrm{Mg}^{2+}\right)$, and $\mathrm{SO}_{4}{ }^{2-}$, as a function of the amount of immobilizer added. The dissolved concentrations of $\mathrm{Ca}^{2+}$ and $\mathrm{Mg}^{2+}$ in RD treatments were higher than those in MRM and increased with the increasing addition of $\mathrm{RD}$, indicating the simultaneous leaching of $\mathrm{Ca}^{2+}$ and $\mathrm{Mg}^{2+}$ from the dissolution of dolomite (Equation (1)). In CD treatments, $\mathrm{Ca}^{2+}$ and $\mathrm{Mg}^{2+}$ were also leached at higher concentrations than those in MRM leachate. At the same amount of CD and RD addition, the leaching concentration of $\mathrm{Mg}^{2+}$ in $\mathrm{CD}$ treatment was higher than that in RD treatment, while almost the same dissolved concentration of $\mathrm{Ca}^{2+}$ was observed in both treatments. This, together with the result that $\mathrm{CD}$ contained less dolomite and more calcite compared to those in $\mathrm{RD}$, suggest the occurrence of hydration of magnesia (Equation (3)) in addition to the dissolution of carbonate minerals (Equations (1) and (2)) in $\mathrm{CD}$ treatments. Moreover, the difference in the leaching concentration of $\mathrm{Mg}^{2+}$ between $\mathrm{CD}$ and RD treatments became more significant as the addition of immobilizers increased, which indicates that as $\mathrm{pH}$ increased, the hydration of magnesia (Equation (3)) played a more important role in controlling 
$\mathrm{pH}$. In MO treatments, the concentration of $\mathrm{Mg}^{2+}$ increased with higher addition of $\mathrm{MO}$, while almost no change in the concentration of $\mathrm{Ca}^{2+}$ from that in MRM was observed. This result suggests the occurrence of hydration of magnesia (Equation (3)) in MO treatments.

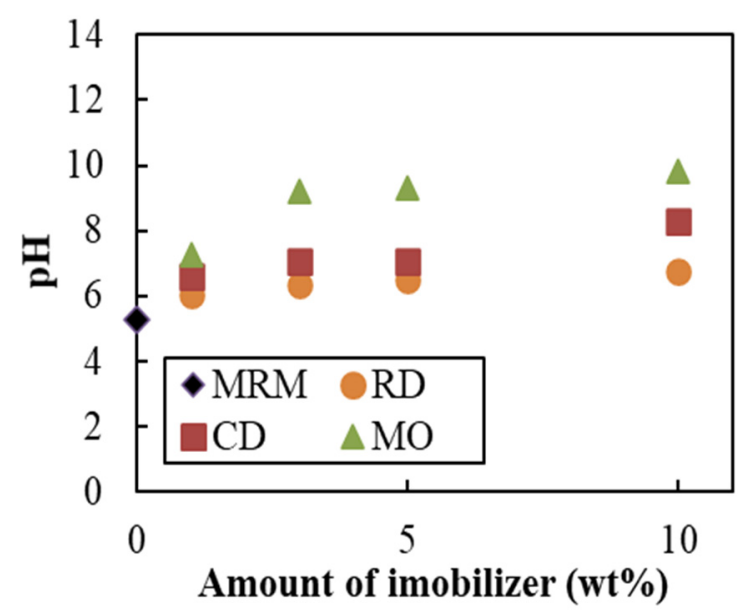

Figure 3. $\mathrm{pH}$ of leachate upon addition of immobilizers.
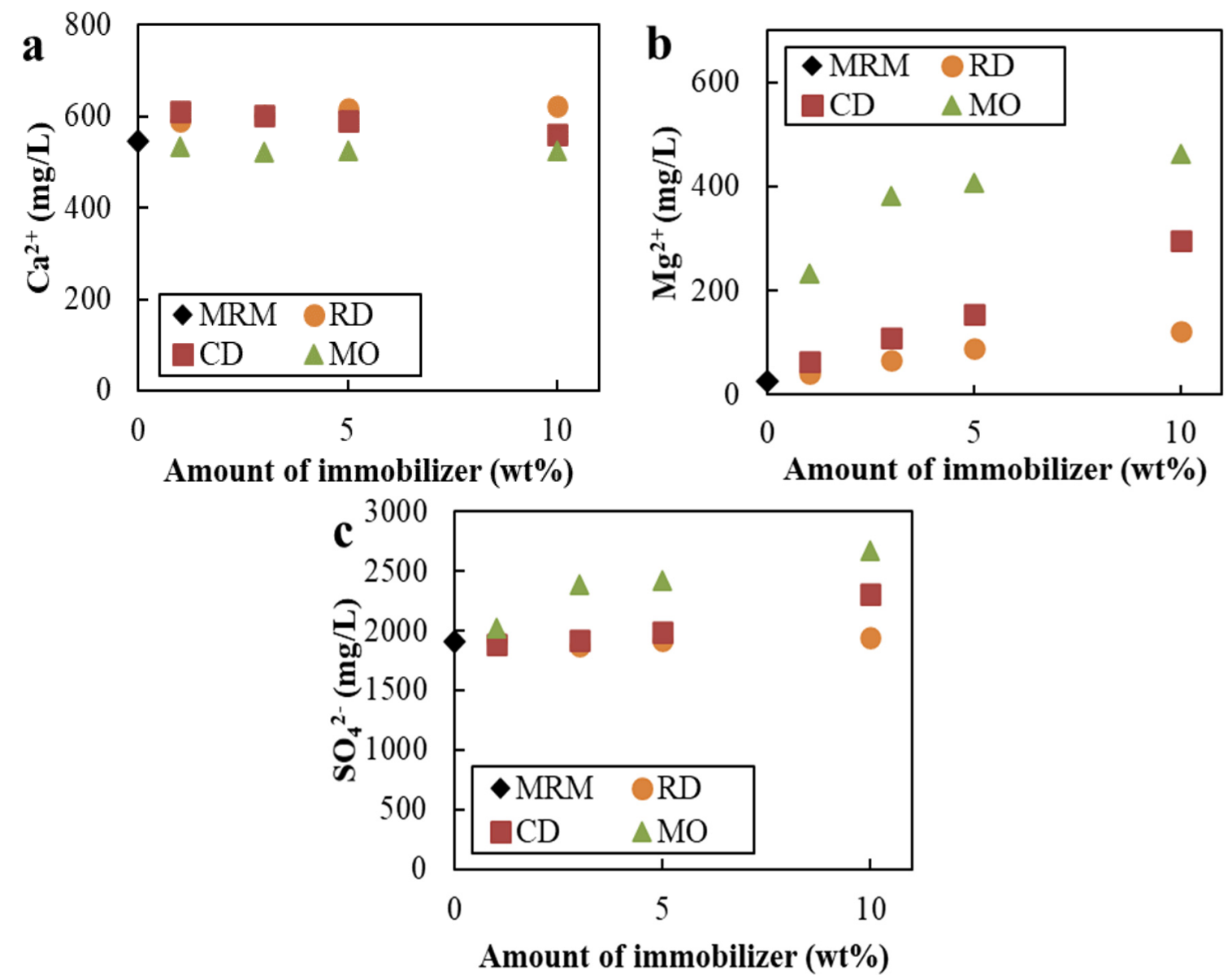

Figure 4. Leaching concentrations of major ions upon addition of immobilizers: (a) $\mathrm{Ca}^{2+},(\mathbf{b}) \mathrm{Mg}^{2+}$, and (c) $\mathrm{SO}_{4}{ }^{2-}$.

At the same amount of immobilizer added, the leaching concentration of $\mathrm{SO}_{4}{ }^{2-}$ was the highest when treating MRM with $\mathrm{MO}$, followed by $\mathrm{CD}$ and $\mathrm{RD}$ (Figure 4c). In consideration of the trace amount of $\mathrm{SO}_{3}$ content in all immobilizers, the results suggest that $\mathrm{MRM}$ should be the source of $\mathrm{SO}_{4}{ }^{2-}$, and the leaching of $\mathrm{SO}_{4}{ }^{2-}$ might be caused by the change in the parameter(s) of the leachate, triggered 
by the addition of immobilizer. Figure 5 illustrates the correlation between the leaching concentration of $\mathrm{SO}_{4}{ }^{2-}$ vs. $\mathrm{pH}$. The $\mathrm{SO}_{4}{ }^{2-}$ concentration exhibited a strong positive correlation with $\mathrm{pH}$ (correlation coefficient $(r)=0.92, p<0.01$ ), suggesting that $\mathrm{SO}_{4}{ }^{2-}$ level could mainly be influenced by $\mathrm{pH}$ due possibly to the following mechanisms: (1) desorption, (2) production by oxidation of sulfide minerals, (3) common-ion of between calcite, dolomite, and gypsum, and (4) dissolution of anglesite. The $\mathrm{pH}$ increase led to a higher negative surface potential of MRM, thereby decreasing the affinity of $\mathrm{SO}_{4}{ }^{2-}$ toward the surface of MRM. However, Tabatabai (1987) [48] reported that since the adsorption of $\mathrm{SO}_{4}{ }^{2-}$ was only flavored under strongly acidic conditions, the amount of adsorbed $\mathrm{SO}_{4}{ }^{2-}$ became almost negligible under weakly acidic $\mathrm{pH}$. This means that the desorption might not be a viable explanation in this study since all leachates' $\mathrm{pH}$ ranged from weakly acidic (5.2) to moderately alkaline (9.8). Therefore, the fact that the oxidation rate of sulfide minerals, such as pyrite and galena, increases with $\mathrm{pH}$ becomes the potential reason contributing to the higher leaching concentration of $\mathrm{SO}_{4}{ }^{2-}[49,50]$. However, the enrichment of $\mathrm{SO}_{4}{ }^{2-}$ could be restricted by the solubility of gypsum because the saturation index of gypsum was within the equilibrium condition range of \pm 0.2 in all leachates. This could explain why the leaching concentration of $\mathrm{SO}_{4}{ }^{2-}$ slightly increased with $\mathrm{pH}$ at lower $\mathrm{pH}$ region where the dissolution of dolomite containing in $\mathrm{RD}$ and calcite and dolomite containing in and $\mathrm{CD}$ tended to control the $\mathrm{pH}$ (Equations (1) and (2)). In other words, $\mathrm{Ca}^{2+}$ produced from the dissolution of calcite and dolomite precipitated with $\mathrm{SO}_{4}{ }^{2-}$ to form gypsum, thereby restricting $\mathrm{SO}_{4}{ }^{2-}$ concentration. Meanwhile, as $\mathrm{pH}$ became more alkaline, the concentration of $\mathrm{SO}_{4}{ }^{2-}$ increased rapidly. This could be attributed to the less contribution of calcite and dolomite dissolution (Equations (1) and (2)) to control the leachate $\mathrm{pH}$ in the case of $\mathrm{CD}$ addition, conjointly in $\mathrm{MO}$ treatments, only hydration of magnesia (no production of $\mathrm{Ca}^{2+}$ ) (Equation (3)) was found to control the $\mathrm{pH}$ of the leachates. The $\mathrm{pH}$-dependent solubility of anglesite could also be attributed to the rapid increase of $\mathrm{SO}_{4}{ }^{2-}$ concentration under alkaline conditions since anglesite was originally contained in MRM and is unstable under alkaline $\mathrm{pH}$ [51].

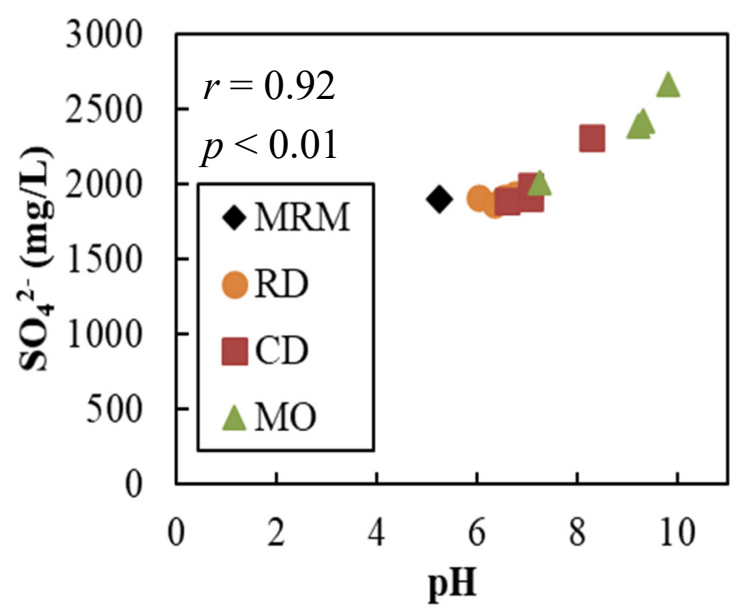

Figure 5. Leaching concentration of $\mathrm{SO}_{4}{ }^{2-}$ vs. $\mathrm{pH}$.

\subsubsection{Effects of the Addition of Immobilizers on Mobility of Heavy Metals}

In this study, the performance of immobilizers was evaluated based on the solubility of $\mathrm{Pb}$ and $\mathrm{Zn}$. Figure $6 \mathrm{a}, \mathrm{b}$ shows the changes in $\mathrm{Pb}$ and $\mathrm{Zn}$ concentrations as a function of the amount of addition of immobilizers. In general, the leaching concentrations of $\mathrm{Pb}$ and $\mathrm{Zn}$ exponentially decreased with an increase in the dose of immobilizers. Figure 7a,b illustrates the correlation between leaching concentrations of $\mathrm{Pb}$ and $\mathrm{Zn}$ vs. $\mathrm{pH}$. The mobility of heavy metals was strongly influenced by $\mathrm{pH}$, indicated by significant negative correlations of $\mathrm{Pb}-\mathrm{pH}(r=-0.92)$ and $\mathrm{Zn}-\mathrm{pH}(r=-0.87)$ at the 0.01 significance level (2-tailed). Coupled with the results of the leaching concentration of $\mathrm{SO}_{4}{ }^{2-}$ and the characteristic of immobilizers, as well as the leaching condition used in the current study, the major modes of $\mathrm{Pb}$ and $\mathrm{Zn}$ attenuation could be either one or more of the following 
mechanisms: precipitations of metal-sulfate, -carbonate, and/or -hydroxide, co-precipitation of metal with iron-(oxy)hydroxides, and metal ion adsorption to immobilizer. The formation of low soluble anglesite under acidic conditions was expected since the leaching concentration of $\mathrm{SO}_{4}{ }^{2-}$ was high and increased with $\mathrm{pH}$ (Figure 5) [52,53]. The carbonate property of $\mathrm{RD}$ and $\mathrm{CD}$ might result in the precipitation of cerussite $\left(\mathrm{PbCO}_{3}\right)$, hydrocerussite $\left(\mathrm{Pb}_{3}\left(\mathrm{CO}_{3}\right)_{2}(\mathrm{OH})_{2}\right)$, smithsonite $\left(\mathrm{ZnCO}_{3}\right)$, and hydrozincite $\left(\mathrm{Zn}_{3}\left(\mathrm{CO}_{3}\right)_{2}(\mathrm{OH})_{2}\right)$ [35,54-56]. The carbonate precipitations of $\mathrm{Pb}$ and $\mathrm{Zn}$ are also expected to occur in $\mathrm{MO}$ treatments since the experiments were done under atmospheric conditions in which carbon dioxide $\left(\mathrm{CO}_{2}\right)$ in the atmosphere was freely dissolved [57]. However, the simulation results by PHREEQC showed that except hydrozincite in 3\% addition of MO treatment, the precipitations of anglesite, cerussite, hydrocerussite, smithsonite, and hydrozincite were thermodynamically unfavorable (saturation index $<-0.2$ ) regardless of the type and amount of immobilizer added (Table 6). Therefore, the possible immobilization mechanisms of $\mathrm{Pb}$ and $\mathrm{Zn}$ in all types of immobilizers could be narrowed down to the hydroxide precipitation, adsorption, and co-precipitation.

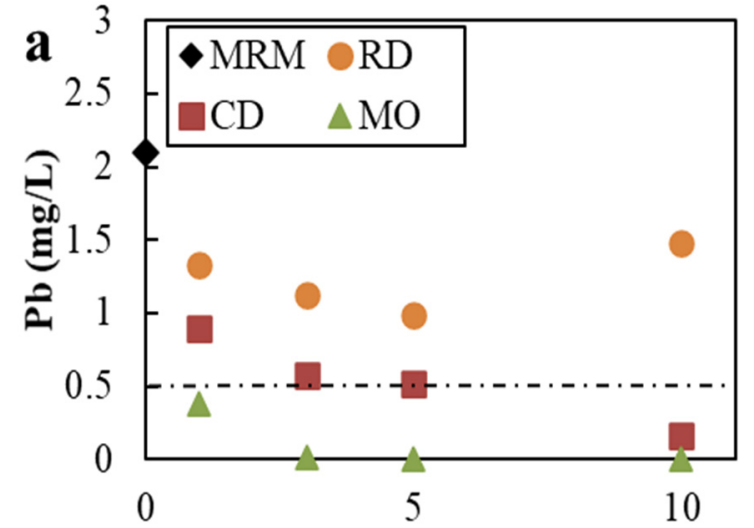

Amount of immobilizer (wt\%)

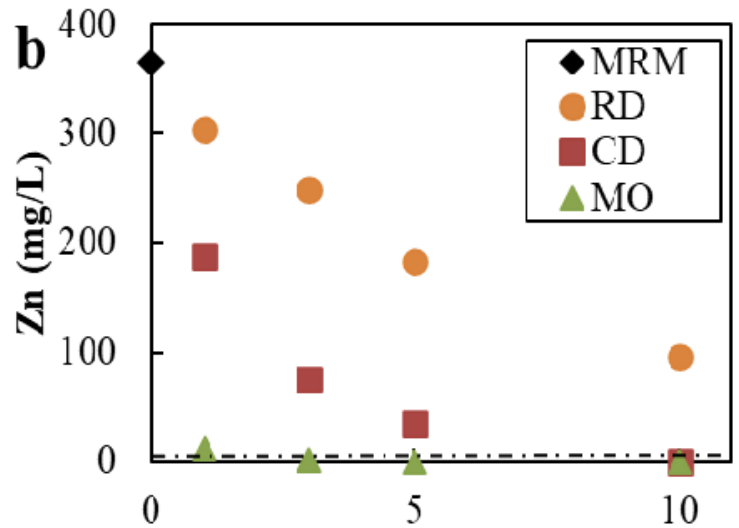

Amount of immobilizer (wt\%)

Figure 6. Leaching concentrations of heavy metals upon addition of immobilizers: (a) $\mathrm{Pb}$ and (b) $\mathrm{Zn}$ (dashed lines represent the effluent standards of $\mathrm{Pb}$ and $\mathrm{Zn}$ in Zambia).
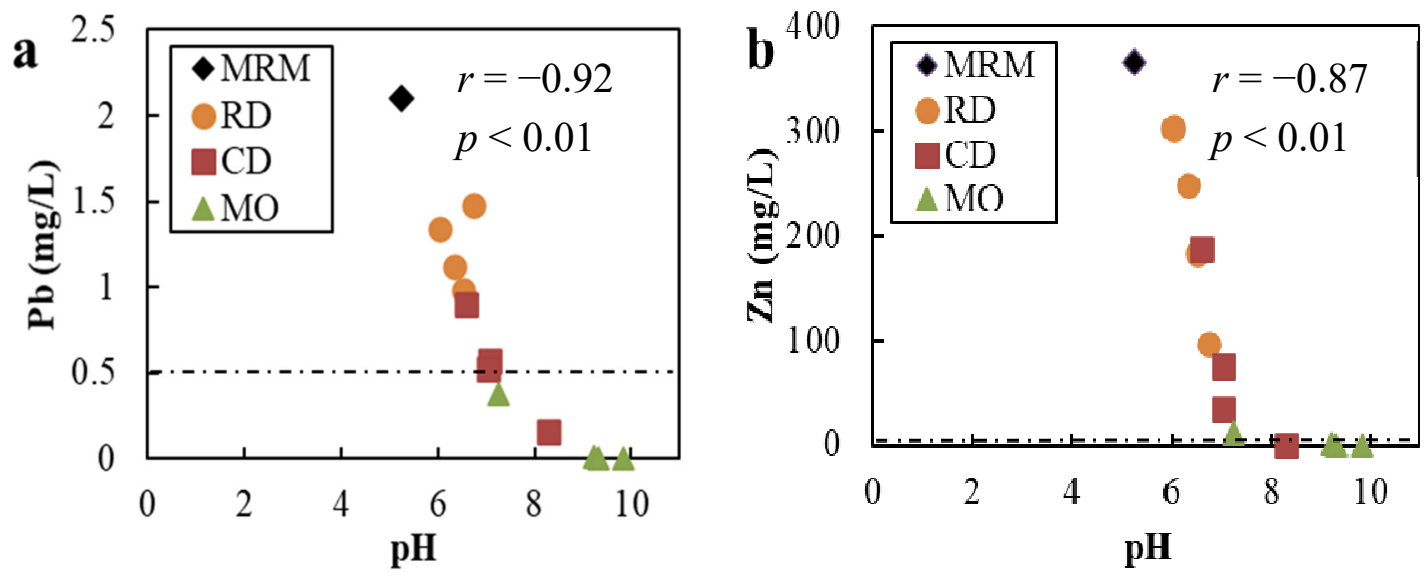

Figure 7. Leaching concentrations of heavy metals vs. $\mathrm{pH}$ : (a) $\mathrm{Pb}$ vs. $\mathrm{pH}$ and (b) $\mathrm{Zn}$ vs. $\mathrm{pH}$ (dash lines represent the effluent standards of $\mathrm{Pb}$ and $\mathrm{Zn}$ in $\mathrm{Zambia}$ ).

To verify the dominant mechanism(s), $\mathrm{pH}$-dependent solubility diagrams of $\mathrm{Pb}$ - and $\mathrm{Zn}$-hydroxides were plotted (Figure 8a,b). Points in the figures represent the relationship between the logarithmic activity of divalent heavy metal and $\mathrm{pH}$ in each batch test. The solid lines demonstrate the solubility of heavy metal hydroxides. Therefore, any point located on or close to the line implies the hydroxide precipitation-controlled sequestration process. 
Table 6. Calculated saturation indices of anglesite, cerussite, hydrocerussite, smithsonite, and hydrozincite in leachates with the addition of RD, CD, and MO.

\begin{tabular}{lcccccc}
\hline \multirow{2}{*}{ Treatment } & & \multicolumn{5}{c}{ Saturation Index } \\
\cline { 3 - 7 } & & Anglesite & Cerussite & Smithsonite & Hydrocerussite & Hydrozincite \\
\hline \multirow{4}{*}{ RD treatments } & $1 \%$ & -0.4 & -1.15 & -1.63 & -5.63 & -1.82 \\
& $3 \%$ & -0.49 & -1.13 & -1.21 & -4.28 & -1.35 \\
& $5 \%$ & -0.55 & -0.98 & -1.13 & -3.68 & -1.17 \\
& $10 \%$ & -0.41 & -0.48 & -1.01 & -2.11 & -1.01 \\
\hline \multirow{5}{*}{ CD treatments } & $1 \%$ & -0.6 & -0.78 & -0.87 & -3.19 & -0.98 \\
& $3 \%$ & -0.92 & -0.27 & -0.44 & -1.56 & -0.48 \\
& $5 \%$ & -0.99 & -0.23 & -0.66 & -1.58 & -0.79 \\
& $10 \%$ & -2.39 & -0.3 & -1.24 & -0.64 & -0.64 \\
\hline \multirow{5}{*}{ MO treatments } & $1 \%$ & -1.13 & -0.38 & -1.16 & -1.57 & -1 \\
& $3 \%$ & -4.36 & -1.6 & -1.16 & -3.31 & 0.22 \\
& $5 \%$ & -4.72 & -1.86 & -2.19 & -4.05 & -0.78 \\
& $10 \%$ & -5.49 & -2.52 & -2.99 & -5.16 & -1.02 \\
\hline
\end{tabular}
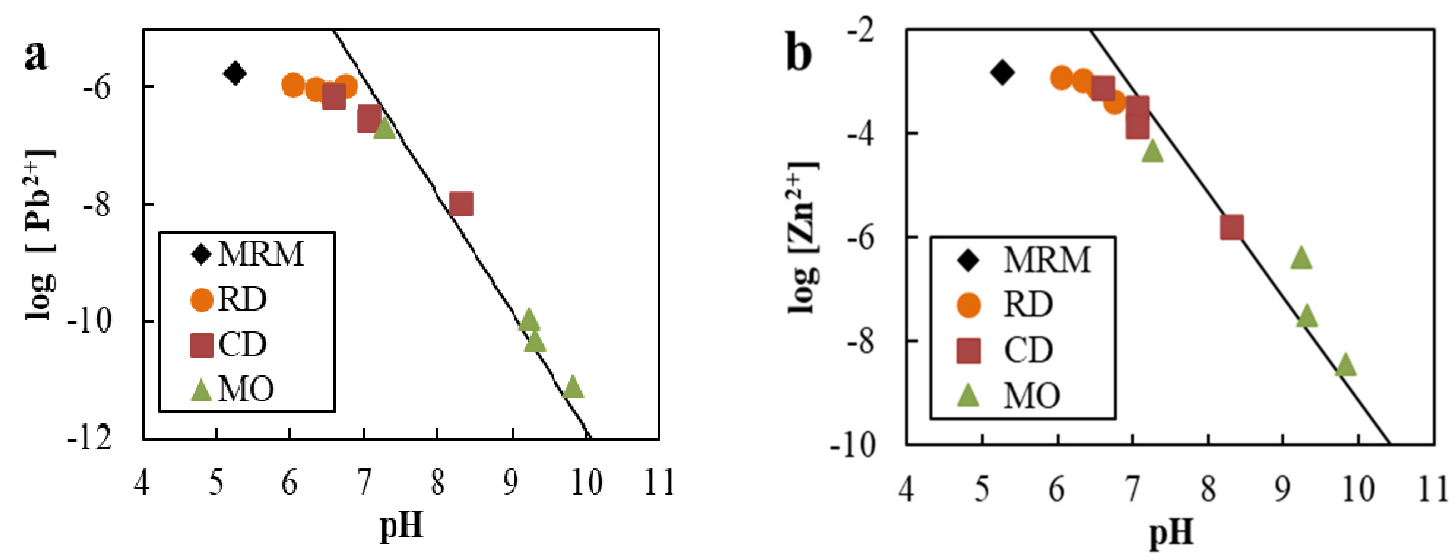

Figure 8. pH-dependent solubility diagrams of (a) Pb-hydroxide and (b) Zn-hydroxide ([ ] represents activity).

In the case of $\mathrm{RD}$ addition, a discrepancy from the equilibrium line for $\mathrm{Pb}$ and $\mathrm{Zn}$ was observed. This means that at $\mathrm{pH}$ from weekly acid to neutral, hydroxide precipitation was not the main mechanism controlling the mobility of $\mathrm{Pb}$ and $\mathrm{Zn}$. Therefore, $\mathrm{Pb}$ and $\mathrm{Zn}$ were suspected to be immobilized by sorption and co-precipitation with iron-(oxy)hydroxides. The sorption was likely to occur since dolomite, major mineral in the immobilizer, can adsorb $\mathrm{Pb}$ and $\mathrm{Zn}[58,59]$. Besides, adding more of this immobilizer induced the leachate $\mathrm{pH}$ increase. This could change the surface charge of goethite, hematite, and iron-(hydr)oxide compounds in MRM to more negative, thereby increasing their adsorption ability against cationic divalent $\mathrm{Pb}$ and $\mathrm{Zn}$ [58-63]. During the neutralization process under ambient conditions, iron-(oxy)hydroxides precipitate from the oxidative dissolution of pyrite and dissolution of iron-bearing salts [63-66]. The precipitations of iron-(oxy)hydroxides have been reported by many studies to induce co-precipitation of divalent metals, including $\mathrm{Pb}$ (II) and $\mathrm{Zn}$ (II) $[50,67,68]$, and thus the co-precipitation of $\mathrm{Pb}$ and $\mathrm{Zn}$ with iron-(oxy)hydroxides was also expected in $\mathrm{RD}$ treatments. From the above explanations, adding more RD should reduce the leaching concentration of both metals. However, leaching concentration of $\mathrm{Pb}$ increased from $0.98 \mathrm{mg} / \mathrm{L}$ to $1.4 \mathrm{mg} / \mathrm{L}$ when RD rose from $5 \%$ to $10 \%$ (Figure $6 \mathrm{a}$ ). This could be attributed to the stability of $\mathrm{Pb}$ (II) species as a function of $\mathrm{pH}$. Theoretically, as $\mathrm{pH}$ increases under acidic region, more of free $\mathrm{Pb}$ (II) ion tends to complex with $\mathrm{OH}^{-}$and $\mathrm{CO}_{3}{ }^{2-}$, generating larger ion with lower charge $\left(\mathrm{Pb}(\mathrm{OH})^{+}\right.$and $\left.\mathrm{PbCO}_{3}\right)$, which lowers the affinity of $\mathrm{Pb}$ to the surface of the potential adsorbents and inhibits the co-precipitation [69-71]. 
On the other hand, adding CD and MO made most of the logarithmic leaching activities of $\mathrm{Pb}^{2+}$ and $\mathrm{Zn}^{2+}$ to approach their solubility product lines. This means that hydroxide precipitation is the dominant mechanism of attenuating $\mathrm{Pb}$ and $\mathrm{Zn}$. Regardless of the type of immobilizer, at low $\mathrm{pH}$, the logarithmic activities of both metals were slightly lower than their equilibrium lines and then tended to stay on or be slightly higher than the lines afterward. This probably indicates that at low $\mathrm{pH}$, adsorption and co-precipitation with iron-(oxy)hydroxides also occurred in addition to the precipitation, but as $\mathrm{pH}$ got higher, they diminished. There are two probable explanations for this phenomenon as follows: (1) competition with strong competing ion $\left(\mathrm{Mg}^{2+}\right)$ and (2) change in specification of the dissolved metals. The $\mathrm{pH}$ alteration mechanisms of $\mathrm{CD}$ and $\mathrm{MO}$ appeared to generate $\mathrm{Mg}^{2+}$ as a by-product (Equations (1) and (3)). Because of this, the concentration of $\mathrm{Mg}^{2+}$ significantly increased with $\mathrm{pH}$ with a correlation coefficient of $0.97, p<0.01$ (Figure 9). Therefore, as $\mathrm{pH}$ increased, high concentration of $\mathrm{Mg}^{2+}$ could compete for $\mathrm{Pb}$ and $\mathrm{Zn}$ for adsorption sites and for co-precipitation with iron-(oxy)hydroxides, attributing to the less contribution of the adsorption and co-precipitation on the immobilization process. Increasing $\mathrm{pH}$ could also result in the redistributions of $\mathrm{Pb}(\mathrm{II})$ and $\mathrm{Zn}$ (II) species. The fraction of free $\mathrm{Pb}(\mathrm{II})$ and $\mathrm{Zn}$ (II) reduces as $\mathrm{pH}$ increases since they are thermodynamically preferable to be hydrolyzed forming $-(\mathrm{OH})^{+},-(\mathrm{OH})_{2}$, and $-(\mathrm{OH})_{3}{ }^{-}[69-72]$. Moreover, since the systems contained high dissolved carbonate, the formation of carbonate complexes of $\mathrm{Pb}(\mathrm{II})$ and $\mathrm{Zn}(\mathrm{II})$ was also expected $[69,73]$. Once these complexes are formed, their abilities to get adsorbed and co-precipitated are inhibited by the larger size and lower positive potential they become.

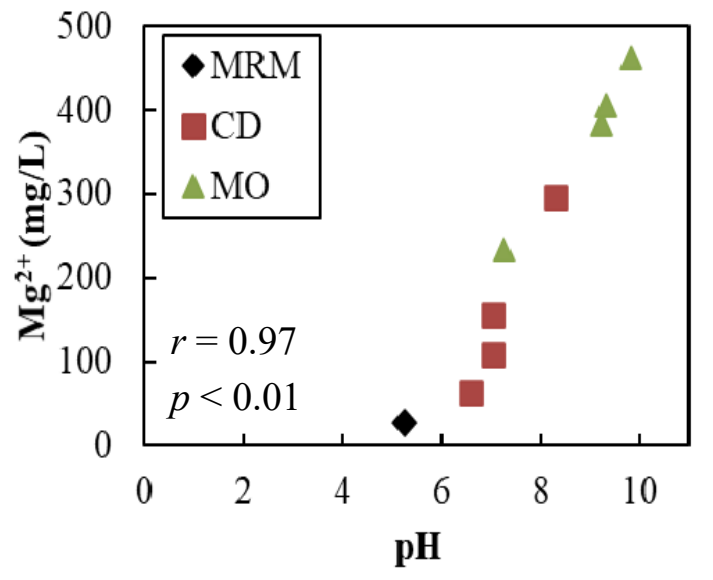

Figure 9. Leaching concentration of $\mathrm{Mg}^{2+}$ vs. $\mathrm{pH}$.

\subsubsection{Performance of Immobilizers}

When the same amount of immobilizer was added, the dissolved concentrations of $\mathrm{Pb}$ and $\mathrm{Zn}$ were the highest in RD treatment, second highest in CD treatment, and the lowest in MO treatment (Figure $6 \mathrm{a}, \mathrm{b})$. As previously mentioned, adsorption, co-precipitation, and hydroxide precipitation were the major sink of $\mathrm{Pb}$ and $\mathrm{Zn}$, and their mobilities depended strongly on $\mathrm{pH}$. Because of the carbonate property of dolomite, $\mathrm{RD}$ could not raise the $\mathrm{pH}$ of MRM leachate to the value favoring the precipitations of $\mathrm{Pb}$ - and $\mathrm{Zn}$-hydroxides. Therefore, $\mathrm{RD}$ treatments remediated $\mathrm{Pb}$ and $\mathrm{Zn}$ by adsorption and co-precipitation in which it was insufficient to reduce the leaching concentrations of $\mathrm{Pb}$ and $\mathrm{Zn}$ down below their regulated values. On the other hand, magnesia in $\mathrm{CD}$ and MO played a significant role in increasing the leachate $\mathrm{pH}$ of MRM into the alkaline region. Lead and $\mathrm{Zn}$ were then mainly immobilized by precipitation as hydroxides. Thus, metal concentrations as high as $368 \mathrm{mg} / \mathrm{L}$ for $\mathrm{Zn}$ and $2.1 \mathrm{mg} / \mathrm{L}$ for $\mathrm{Pb}$ released from MRM were reduced to the values below their regulated concentrations. Efficiency-wise, $\mathrm{MO}$ was the most effective immobilizer in immobilizing $\mathrm{Pb}$ and $\mathrm{Zn}$ since it contained the highest $\mathrm{MgO}$ content. However, $\mathrm{CD}$ could be the immobilizer of choice since it can be produced from the naturally abundant material in Zambia (RD), and its performance was almost the same as that of MO. 


\section{Conclusions}

The leachate of MRM was slightly acidic ( $\mathrm{pH}$ 5.2) and contained high concentrations of $\mathrm{Pb}$ $(2.1 \mathrm{mg} / \mathrm{L})$ and $\mathrm{Zn}(365 \mathrm{mg} / \mathrm{L})$, exceeding those of Zambian regulation. When immobilizers were introduced, the leachate $\mathrm{pH}$ increased, and the leaching concentrations of $\mathrm{Pb}$ and $\mathrm{Zn}$ decreased. Lead and $\mathrm{Zn}$ immobilized by RD were interpreted by the adsorption and co-precipitation mechanisms. On the contrary, chemical immobilization using $\mathrm{CD}$ and $\mathrm{MO}$ suppressed $\mathrm{Pb}$ and $\mathrm{Zn}$ leaching mainly by the hydroxide precipitation. Of the immobilizers investigated, only $\mathrm{CD}$ and $\mathrm{MO}$ decreased the dissolved $\mathrm{Pb}$ and $\mathrm{Zn}$ concentrations to below their regulated values, in which $\mathrm{MO}$ had a higher performance than $\mathrm{CD}$. The results show that heat treatment on $\mathrm{RD}$ to produce $\mathrm{CD}$ drastically improved the immobilizing performance of $\mathrm{Pb}$ and $\mathrm{Zn}$. Even though $\mathrm{MO}$ provided the highest efficiency, $\mathrm{Pb}$ and $\mathrm{Zn}$ could also be effectively immobilized by giving an adequate amount of $\mathrm{CD}$. Therefore, by considering the availability of $\mathrm{CD}$ in the local area, $\mathrm{CD}$ could be the most promising chemical agent to be implemented in Zambia.

Author Contributions: Conceptualization, P.T.; methodology, P.T., K.N., T.I., and T.K.; formal analysis, P.T. and T.I.; writing—original draft preparation, P.T.; writing—review and editing, P.T., T.I., M.I. (Mayumi Ito), T.S., W.M., M.C., and I.N.; supervision, P.T. and T.I.; project administration, M.I. (Mayumi Ishizuka), S.N., and H.N.; funding acquisition, M.I. (Mayumi Ishizuka), S.N., and H.N.; All authors have read and agreed to the published version of the manuscript.

Funding: This research was supported by JST/JICA SATREPS (Science and Technology Research Partnership for Sustainable Development; No. JPMJSA1501) and aXis (Accelerating Social Implementation for SDGs Achievement; No. JPMJAS2001) funded by JST.

Acknowledgments: The authors would like to acknowledge JST/JICA SATREPS (Science and Technology Research Partnership for Sustainable Development; No. JPMJSA1501) and aXis (Accelerating Social Implementation for SDGs Achievement; No. JPMJAS2001) funded by JST for the financial support.

Conflicts of Interest: The authors declare no conflict of interest.

\section{References}

1. Kamona, A.F.; Friedrich, G.H. Geology, mineralogy, and stable isotope geochemistry of the Kabwe carbonate-hosted $\mathrm{Pb}-\mathrm{Zn}$ deposit, Central Zambia. Ore Geol. Rev. 2007, 30, 217-243. [CrossRef]

2. Kříbek, B.; Nyambe, I.; Majer, V.; Knésl, I.; Mihaljevič, M.; Ettler, V.; Vaněk, A.; Penížek, V.; Sracek, O. Soil contamination near the Kabwe $\mathrm{Pb}-\mathrm{Zn}$ smelter in Zambia: Environmental impacts and remediation measures proposal. J. Geochem. Explor. 2019, 197, 159-173. [CrossRef]

3. Fuge, R.; Pearce, M.F.; Pearce, N.J.G.; Perkins, W.T. Geochemistry of Cd in the secondary environment near abandoned metalliferous mines, Wales. J. Appl. Geochem. 1993, 8, 29-35. [CrossRef]

4. Paulson, A.J. The transport and fate of $\mathrm{Fe}, \mathrm{Mn}, \mathrm{Cu}, \mathrm{Zn}, \mathrm{Cd}, \mathrm{Pb}$ and $\mathrm{SO} 4$ in a groundwater plume and in downstream surface waters in the Coeur d'Alene Mining District, Idaho, U.S.A. J. Appl. 1997, 12, 447-464. [CrossRef]

5. Yabe, J.; Nakayama, S.M.M.; Ikenaka, Y.; Muzandu, K.; Ishizuka, M.; Umemura, T. Uptake of lead, cadmium, and other metals in the liver and kidneys of cattle near a lead-zinc mine in Kabwe, Zambia. Environ. Toxicol. Chem. 2011, 30, 1892-1897. [CrossRef]

6. Yabe, J.; Nakayama, S.M.M.; Ikenaka, Y.; Muzandu, K.; Choongo, K.; Mainda, G.; Kabeta, M.; Ishizuka, M.; Umemura, T. Metal distribution in tissues of free-range chickens near a lead-zinc mine in Kabwe, Zambia. Environ. Toxicol. Chem. 2013, 32, 189-192. [CrossRef]

7. Yabe, J.; Nakayama, S.M.M.; Ikenaka, Y.; Yohannes, Y.B.; Bortey-Sam, N.; Oroszlany, B.; Muzandu, K.; Choongo, K.; Kabalo, A.N.; Ntapisha, J.; et al. Lead poisoning in children from townships in the vicinity of a lead-zinc mine in Kabwe, Zambia. Chemosphere 2015, 119, 941-947. [CrossRef]

8. Yabe, J.; Nakayama, S.M.M.; Ikenaka, Y.; Yohannes, Y.B.; Bortey-Sam, N.; Kabalo, A.N.; Ntapisha, J.; Mizukawa, H.; Umemura, T.; Ishizuka, M. Lead and cadmium excretion in feces and urine of children from polluted townships near a lead-zinc mine in Kabwe, Zambia. Chemosphere 2018, 202, 48-55. [CrossRef]

9. Basta, N.T.; McGowen, S.L. Evaluation of chemical immobilization treatments for reducing heavy metal transport in a smelter-contaminated soil. Environ. Pollut. 2004, 127, 73-82. [CrossRef] 
10. Silwamba, M.; Ito, M.; Hiroyoshi, N.; Tabelin, C.B.; Hashizume, R.; Fukushima, T.; Park, I.; Jeon, S.; Igarashi, T.; Sato, T.; et al. Recovery of lead and zinc from zinc plant leach residues by concurrent dissolution-cementation using zero-valent aluminum in chloride medium. Metals 2020, 10, 531. [CrossRef]

11. Silwamba, M.; Ito, M.; Hiroyoshi, N.; Tabelin, C.B.; Fukushima, T.; Park, I.; Jeon, S.; Igarashi, T.; Sato, T.; Nyambe, I.; et al. Detoxification of lead-bearing zinc plant leach residues from Kabwe, Zambia by coupled extraction-cementation method. J. Environ. Chem. Eng. 2020, 8, 104197. [CrossRef]

12. Mwandira, W.; Nakashima, K.; Kawasaki, S.; Ito, M.; Sato, T.; Igarashi, T.; Banda, K.; Chirwa, M.; Nyambe, I.; Nakayama, S.; et al. Efficacy of biocementation of lead mine waste from the Kabwe Mine site evaluated using Pararhodobacter sp. Environ. Sci. Pollut. Res. 2019, 26, 15653-15664. [CrossRef] [PubMed]

13. Mwandira, W.; Nakashima, K.; Kawasaki, S.; Ito, M.; Sato, T.; Igarashi, T.; Chirwa, M.; Banda, K.; Nyambe, I.; Nakayama, S.; et al. Solidification of sand by $\mathrm{Pb}(\mathrm{II})$-tolerant bacteria for capping mine waste to control metallic dust: Case of the abandoned Kabwe Mine, Zambia. Chemosphere 2019, 228, 17-25. [CrossRef] [PubMed]

14. Liu, L.; Li, W.; Song, W.; Guo, M. Remediation techniques for heavy metal-contaminated soils: Principles and applicability. Sci. Total Environ. 2018, 633, 206-219. [CrossRef]

15. Gray, C.W.; Dunham, S.J.; Dennis, P.G.; Zhao, F.J.; McGrath, S.P. Field evaluation of in situ remediation of a heavy metal contaminated soil using lime and red-mud. Environ. Pollut. 2006, 142, 530-539. [CrossRef]

16. Kumpiene, J.; Lagerkvist, A.; Maurice, C. Stabilization of As, $\mathrm{Cr}, \mathrm{Cu}, \mathrm{Pb}$ and $\mathrm{Zn}$ in soil using amendmentsA review. J. Waste Manag. 2008, 28, 215-225. [CrossRef]

17. Farrell, M.; Jones, D.L. Use of composts in the remediation of heavy metal contaminated soil. J. Hazard. Mater. 2010, 175, 575-582. [CrossRef]

18. He, M.; Shi, H.; Zhao, X.; Yu, Y.; Qu, B. Immobilization of Pb and Cd in contaminated soil using nano-crystallite hydroxyapatite. Procedia Environ. Sci. 2013, 18, 657-665. [CrossRef]

19. Bolan, N.; Kunhikrishnan, A.; Thangarajan, R.; Kumpiene, J.; Park, J.; Makino, T.; Kirkham, M.B.; Scheckel, K. Remediation of heavy metal(loid)s contaminated soils—To mobilize or to immobilize? J. Hazard. Mater. 2014, 266, 141-166. [CrossRef]

20. Mahar, A.; Wang, P.; Li, R.; Zhang, Z. Immobilization of lead and cadmium in contaminated soil using amendments: A review. Pedosphere 2015, 25, 555-568. [CrossRef]

21. Ali, A.; Guo, D.; Zhang, Y.; Sun, X.; Jiang, S.; Guo, Z.; Huang, H.; Liang, W.; Li, R.; Zhang, Z. Using bamboo biochar with compost for the stabilization and phytotoxicity reduction of heavy metals in mine-contaminated soils of China. Sci. Rep. 2017, 7, 2690. [PubMed]

22. Seshadri, B.; Bolan, N.S.; Choppala, G.; Kunhikrishnan, A.; Sanderson, P.; Wang, H.; Currie, L.D.; Tsang, D.C.W.; Ok, Y.S.; Kim, G. Potential value of phosphate compounds in enhancing immobilization and reducing bioavailability of mixed heavy metal contaminants in shooting range soil. Chemosphere 2017, 184, 197-206. [CrossRef]

23. Andrunik, M.; Wołowiec, M.; Wojnarski, D.; Zelek-Pogudz, S.; Bajda, T. Transformation of Pb, Cd, and Zn minerals using phosphates. Minerals 2020, 10, 342. [CrossRef]

24. Southwood, M.; Cairncross, B.; Rumsey, M.S. Minerals of the Kabwe ("Broken Hill”) mine, central province, Zambia. Rocks Miner. 2019, 94, 114-149. [CrossRef]

25. Trakal, L.; Neuberg, M.; Tlustoš, P.; Száková, J.; Tejnecký, V.; Drábek, O. Dolomite limestone application as a chemical immobilization of metal-contaminated soil. Plant Soil Environ. 2011, 4, 173-179.

26. Deer, W.A.; Howie, R.A.; Zussman, J. An Introduction to The Rock Forming Minerals, 2nd ed.; Longmans: London, UK, 1966; pp. 489-493.

27. Krauskopf, K.B.; Bird, D.K. Introduction to Geochemistry, 3rd ed.; McGraw-Hill: New York, NY, USA, 1995.

28. Salameh, Y.; Albadarin, A.B.; Allen, S.; Walker, G.; Ahmad, M.N.M. Arsenic (III,V) adsorption onto charred dolomite: Charring optimization and batch studies. Chem. Eng. J. 2015, 259, 663-671. [CrossRef]

29. JLT-13. Departmental notification No. 13 on leaching test method for landfill wastes. Jap. Environ. Agcy. 1973. Available online: http://www.env.go.jp/hourei/11/000178.html (accessed on 26 August 2020).

30. Tessier, A.; Campbell, G.C.; Bisson, M. Sequential extraction procedure for the speciation of particulate trace metals. Anal. Chem. 1979, 51, 844-850.

31. Clevenger, T.E. Use of sequential extraction to evaluate the heavy metals in mining wastes. Water Air Soil Pollut. 1990, 50, 241-253. 
32. Marumo, K.; Ebashi, T.; Ujiie, T. Heavy metal concentrations, leachabilities and lead isotope ratios of Japanese soils. Shigen Chihsitsu 2003, 53, 125-146. (In Japanese)

33. Dang, Z.; Liu, C.; Haigh, M.J. Mobility of heavy metals associated with the natural weathering of coal mine spoils. Environ. Pollut. 2002, 118, 419-426. [CrossRef]

34. Anju, M.; Banerjee, D.K. Comparison of two sequential extraction procedures for heavy metal partitioning in mine tailings. Chemosphere 2010, 78, 1393-1402. [CrossRef] [PubMed]

35. Tabelin, C.B.; Silwamba, M.; Paglinawan, F.C.; Mondejar, A.J.S.; Duc, H.G.; Resabal, N.J.; Opiso, E.M.; Igarashi, T.; Tomiyama, S.; Ito, M.; et al. Solid-phase partitioning and release-retention mechanisms of copper, lead, zinc and arsenic in soils impacted by artisanal and small-scale gold mining (ASGM) activities. Chemosphere 2020, 260, 127574. [CrossRef] [PubMed]

36. Khoeurn, K.; Sasaki, A.; Tomiyama, S.; Igarashi, T. Distribution of zinc, copper, and iron in the tailings dam of an abandoned mine in Shimokawa, Hokkaido, Japan. Mine Water Environ. 2018, 38, 119-129. [CrossRef]

37. Parkhurst, D.L.; Appelo, C.A.J. User's guide to PHREEQC (Version 2): A computer program for speciation, batch-reaction, one-dimensional transport, and inverse geochemical calculations. Water Resour. Investig. Rep. 1999, 99, 312.

38. Blowes, D.W.; Jambor, J.L.; Alpers, C.N. The environmental geochemistry of sulfide mine-wastes. Mineral. Assoc. Can. 1994, 22, 59-102.

39. Hayes, S.M.; White, S.A.; Thompson, T.L.; Maier, R.M.; Chorover, J. Changes in lead and zinc lability during weathering-induced acidification of desert mine tailings: Coupling chemical and micro-scale analyses. Appl. Geochem. 2009, 42, 2234-2245. [CrossRef]

40. Wuana, R.A.; Okieimen, F.E. Heavy metals in contaminated soils: A review of sources, chemistry, risks and best available strategies for remediation. ISRN Ecol. 2011, 2011, 20. [CrossRef]

41. The Environment Management Act. The environment management (licensing) regulations. SI Govt. Zambia 2013, 112, 737-858.

42. Klimchouk, A.B. The dissolution and conversion of gypsum and anhydrite. Speleolog 1996, 25, 21-36. [CrossRef]

43. Hester, R.E.; Harrison, R.M. Contaminated Land and Its Reclamation, 1st ed.; Royal Society of Chemistry: London, UK, 1997.

44. Lui, Z.; Dreybrodt, W. Dissolution kinetics of calcium carbonate minerals in $\mathrm{H}_{2} \mathrm{O}-\mathrm{CO}_{2}$ solutions in turbulent flow: The role of the diffusion boundary layer and the slow reaction $\mathrm{H}_{2} \mathrm{O}+\mathrm{CO}_{2} \leftrightarrow \mathrm{H}^{+}+\mathrm{HCO}_{3}{ }^{-}$. Geochem. Cosmochim. Acta 1997, 61, 2879-2889.

45. Pokrovsky, O.S.; Schott, J.N. Kinetics and mechanism of dolomite dissolution in neutral to alkaline solutions revisited. Am. J. Sci. 2001, 301, 597-626. [CrossRef]

46. Fu, J.; He, Q.; Miedziak, P.J.; Brett, G.L.; Huang, X.; Pattisson, S.; Douthwaite, M.; Hutchings, G.J. The role of $\mathrm{Mg}(\mathrm{OH})_{2}$ in the so-called "base-free" oxidation of glycerol with Au Pd catalysts. Chemistry 2018, 24, 2396-2402. [CrossRef]

47. Xing, Z.; Bai, L.; Ma, Y.; Wang, D.; Li, M. Mechanism of magnesium oxide hydration based on the multi-rate model. Materials 2018, 11, 1835. [CrossRef] [PubMed]

48. Tabatabai, M.A. Physicochemical fate of sulfate in soils. JAPCA 1987, 37, 34-38. [CrossRef]

49. Evangelou, V.P. Pyrite Oxidation and Its Control, 1st ed.; CRC Press: New York, NY, USA, 1995.

50. Tabelin, C.B.; Igarashi, T.; Tabelin, M.V.; Park, I.; Opiso, E.M.; Ito, M.; Hiroyoshi, N. Arsenic, selenium, boron, lead, cadmium, copper, and zinc in naturally contaminated rocks: A review of their sources, modes of enrichment, mechanisms of release, and mitigation strategies. Sci. Total Environ. 2018, 645, 1522-1553. [CrossRef]

51. Cappuyns, V.; Alian, V.; Vassilieva, E.; Swennen, R. pH dependent leaching behavior of Zn, Cd, Pb, Cu and as from mining wastes and slags: Kinetics and mineralogical control. Waste Biomass Valor. 2014, 5, 355-368. [CrossRef]

52. Lindsay, W.L. Chemical Equilibria in Soils, 1st ed.; Wiley: Hoboken, NJ, USA, 1979.

53. Tatsuhara, T.; Arima, T.; Igarashi, T.; Tabelin, C.B. Combined neutralization-adsorption system for the disposal of hydrothermally altered excavated rock producing acidic leachate with hazardous elements. Eng. Geol. 2012, 139, 76-84. [CrossRef]

54. McBride, M.B. Reactions controlling heavy metal solubility in soils. Adv. Soil Sci. 1989, 10, 1-56. 
55. Mench, M.J.; Didier, V.L.; Leoffler, M.; Gomez, A.; Pierre, M. A mimicked in-situ remediation study of metal-contaminated soils with emphasis on cadmium and lead. J. Environ. Qual. 1994, 23, 58-63. [CrossRef]

56. Chlopecka, A.; Adriano, D.C. Mimicked in-situ stabilization of metals in a cropped soil: Bioavailability and chemical form of zinc. Environ. Sci. Technol. 1996, 30, 3294-3303. [CrossRef]

57. Carbonate Equilibria in Natural Waters. Available online: https://www.fkit.unizg.hr/_download/repository/ CO2_ravnoteza\%5B1\%5D.pdf (accessed on 20 July 2020).

58. Tozsin, G. Inhibition of acid mine drainage and immobilization of heavy metals from copper flotation tailings using marble cutting waste. Int. J. Min. Met. Mater. 2016, 23, 1-6. [CrossRef]

59. Gruszecka-Kosowska, A.; Baran, P.; Wdowin, M.; Franus, W. Waste dolomite powder as an waste dolomite powder as an adsorbent of $\mathrm{Cd}, \mathrm{Pb}(\mathrm{II})$, and $\mathrm{Zn}$ from aqueous solutions. Environ. Earth. Sci. 2017, 79, 521. [CrossRef]

60. Gadde, R.R.; Laitinen, H.A. Studies of heavy metal adsorption by hydrous iron and manganese oxides. Anal. Chem. 1974, 46, 2022-2026. [CrossRef]

61. Millward, G.E.; Moore, R.M. The adsorption of $\mathrm{Cu}, \mathrm{Mn}$ and $\mathrm{Zn}$ by iron oxyhydroxide in model estuarine solutions. Water Res. 1982, 16, 981-985. [CrossRef]

62. Tangviroon, P.; Endo, Y.; Fujinaga, R.; Kobayashi, M.; Igarashi, T.; Yamamoto, T. Change in arsenic leaching from silty soil by adding slag cement. Water Air Soil Pollut. 2020, 231, 259. [CrossRef]

63. Marove, C.A.; Tangviroon, P.; Tabelin, C.B.; Igarashi, T. Leaching of hazardous elements from Mozambican coal and coal ash. J. Afr. Earth Sci. 2020, 168, 103861. [CrossRef]

64. Tangviroon, P.; Hayashi, R.; Igarashi, T. Effects of additional layer(s) on the mobility of arsenic from hydrothermally altered rock in laboratory column experiments. Water Air Soil Pollut. 2017, $228,191$. [CrossRef]

65. Tangviroon, P.; Igarashi, T. Modeling and evaluating the performance of river sediment on immobilizing arsenic from hydrothermally altered rock in laboratory column experiments with Hydrus-1D. Water Air Soil Pollut. 2017, 228, 465. [CrossRef]

66. Huyen, D.T.; Tabelin, C.B.; Thuan, H.M.; Dang, D.H.; Truong, P.T.; Vongphuthone, B.; Kobayashi, M.; Igarashi, T. The solid-phase partitioning of arsenic in unconsolidated sediments of the Mekong Delta, Vietnam and its modes of release under various conditions. Chemosphere 2019, 233, 512-523. [CrossRef]

67. Igarashi, T.; Herrera, P.S.; Uchiyama, H.; Miyamae, H.; Iyatomi, N.; Hashimoto, K.; Tabelin, C.B. The two-step neutralization ferrite-formation process for sustainable acid mine drainage treatment: Removal of copper, zinc and arsenic, and the influence of coexisting ions on ferritization. Sci. Total Environ. 2020, 715, 136877. [CrossRef] [PubMed]

68. HoungAloune, S.; Kawaai, T.; Hiroyoshi, N.; Ito, M. Study on schwertmannite production from copper heap leach solutions and its efficiency in arsenic removal from acidic sulfate solutions. Hydrometallurgy 2014, 147, 30-40. [CrossRef]

69. Powell, K.J.; Brown, P.L.; Byrne, R.H.; Gajda, T.; Hefter, G.; Leuz, A.K.; Sjöberg, S.; Wanner, H. Chemical speciation of environmentally significant metals with inorganic ligands, Part 3. The $\mathrm{Pb}^{2+}, \mathrm{OH}^{-}, \mathrm{Cl}^{-}, \mathrm{CO}_{3}{ }^{2-}$, $\mathrm{SO}_{4}{ }^{2-}$, and $\mathrm{PO}_{4}{ }^{3-}$ systems. IUPAC Technical Report. Pure Appl. Chem. 2009, 81, 2425-2476. [CrossRef]

70. Badawy, S.H.; Helal, M.I.D.; Chaudri, A.M.; Lawlor, K.; McGrath, S.P. Heavy metals in the environment. Soil solid-phase controls lead activity in soil solution. J. Environ. Qual. 2002, 31, 162-167. [CrossRef]

71. Namieśnik, J.; Rabajczyk, A. The speciation and physicochemical forms of metals in surface waters and sediments. Chem. Speciat. Bioavailab. 2010, 22, 1-24. [CrossRef]

72. Masliy, A.N.; Shapnik, M.S.; Kuznetsov, A.M. Quantum-chemical investigation of electrochemical processes. Part I. Investigation of the mechanism of $\mathrm{Zn}(\mathrm{II})$ complex electroreduction from alkaline water solutions. Quantum chemical simulation, chemistry, and computational simulation. Butlerov. Commun. 2000, 3, 1-6.

73. Fouillac, C.; Criaud, A. Carbonate and bicarbonate trace metal complexes: Critical reevaluation of stability constants. Geochem. J. 1984, 18, 297-303. [CrossRef]

(C) 2020 by the authors. Licensee MDPI, Basel, Switzerland. This article is an open access article distributed under the terms and conditions of the Creative Commons Attribution (CC BY) license (http://creativecommons.org/licenses/by/4.0/). 